\title{
EAl Endorsed Transactions

\section{Energy-Aware Routing Protocols for Wireless Sensor Network Based on Fuzzy Logic: A 10-Years Analytical Review}

\author{
Anshu Kumar Dwivedi ${ }^{1, *}$, A. K. Sharma ${ }^{1}$, Pawan Singh Mehra ${ }^{2, *}$ \\ ${ }^{1}$ Department of Computer science \& Engg, Madan Mohan Malaviya University of Technology, Gorakhpur, India. \\ ${ }^{2}$ Department of Computer Science \& Engg, Jaypee Institute of information Technology, Noida-62, India.
}

\begin{abstract}
Wireless sensor networks (WSNs) have limited storage capacity, communication bandwidth, processing speed, and battery issues. All these factors affect the lifespan of a WSN. Solving all these issues and increasing the lifespan of the WSN. Energy optimization in WSNs is a demanding issue that drives a huge effort in research and various standardization procedures have been undertaken in this area for the past several years. To deal with the reduction of energy consumption issues in WSNs, various clustering protocols have evolved. In this context, some protocols select an appropriate node as the cluster head to extend the lifespan of the network and also clustering reviewed techniques. In this paper, different fuzzy-based clustering methods are discussed which is helpful in designing novel energy-efficient fuzzy-based routing protocols for WSN. The main purpose of this article is to review different types of routing protocols with their advantages and limitations. In addition, various protocols have been compared graphically with their lifetimes. Various tables are depicted which are helpful for extended studies, graphical comparison between the latest clustering techniques shows the most suitable clustering technique for improving network lifetime.
\end{abstract}

Keywords: fuzzy logic, energy efficient, cluster head, Non-cluster head, network lifetime.

Received on 16 March 2020, accepted on 01 October 2020, published on 06 October 2020

Copyright (C) 2020 Anshu Kumar Dwivedi et al., licensed to EAI. This is an open access article distributed under the terms of the Creative Commons Attribution licence (http://creativecommons.org/licenses/by/3.0/), which permits unlimited use, distribution and reproduction in any medium so long as the original work is properly cited.

doi: 10.4108/eai.6-10-2020.166548

*Corresponding author: Email: anshucse.dwivedi@gmail.com Email: pawansinghmehra@gmail.com

\section{Introduction}

WSN gathered the information from the environment and maintain it for long period. WSN contains the sensor nodes, which can sense, collect, and compute data from surrounding. These SN uses a huge battery power supply, large memory, and powerful processor. So, now this becomes the issue for researches that how to efficiently use the energy of SN. WSN can be categorized into two parts i.e. homogeneous and heterogeneous. In homogeneous $\mathrm{n} / \mathrm{w}$ the characteristics of all SN are the same but it is not with the heterogeneous network. Sensor nodes are deployed in a large area and communicate with each other via wireless technology. These sensor nodes are small [1], [2], having less memory, limited bandwidth operates on battery, limited speed, and low cost. Due to the restricted resources that each sensor node has, the optimization of energy utilization is a big issue in the field of WSNs. So our research work is mainly centralized to energy-aware MAC protocol, power awareness on system-level, radio communication, and duty cycle issue. There are various challenges facing in developing the routes for data transmission at the network layer. Some of the challenges include are lack of global addressing, not an implementation of traditionally IP based routing, and redundancy of sensed data. By keeping these all challenges in mind, various routing protocols have been proposed. It includes data-centric, location-based protocol; QoS based protocol, and hierarchical protocol. Data-centric is a query-based protocol and it helps in query data and for data redundancy. The location-based protocol transmits the data from source to sink node based on location. Hierarchical protocol collects the data from non- clusterto-cluster nodes and forms cluster. QoS protocol transmits 
only those data to Sink, which satisfy some of the QoS criteria. Now a days, fuzzy logic based application used in WSNs[3][4] and many more. Various fuzzy logic based system have came out $[5][6][7][8][9][10][11][12][13][14][15]$. In a fuzzy logicbased system, the sensor nodes are position arbitrarily in a real-time environment. The fuzzy logic method takes input as the distance of a node to sink and the node's residual energy and gives the output as the probability of becoming $\mathrm{CH}$. This method gives better result than LEACH. Gupta [14] gave earlier used fuzzy theory. In order to increase lifespan, local information of the node must be known that include distance of node to sink node, the node's energy level as well as local density .Max-min colony optimization [10][16], [17] are used for balance energy consumption among $\mathrm{CHs}$. To select suitable $\mathrm{CHs}$ in real time to reduce energy consumption, Cluster Head Election Mechanism using Fuzzy Logic (CHEF) was came as depict in figure 1. Energy aware distributed clustering protocol which uses fuzzy logic(ECPE) is also developed to diminish energy utilization by sensor nodes[10][18] along with this ACO(UCFIA) and IFUC were suggested by Mao[5].

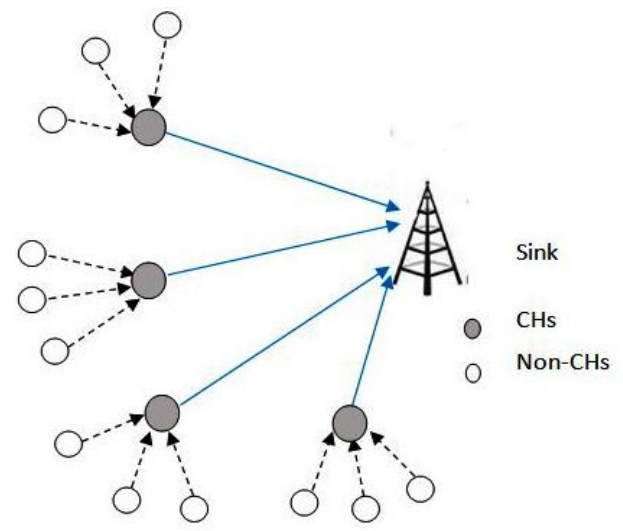

Figure 1. Data Routing via Cluster head

In this literature survey show that last 10 year publication report based on energy aware routing protocol for WSN in Figure 2 and also depict sequential distribution of the papers. Figure 3 [19] demonstrate the estimate rise in revenues from the WSN market for the period of 2010-2014.

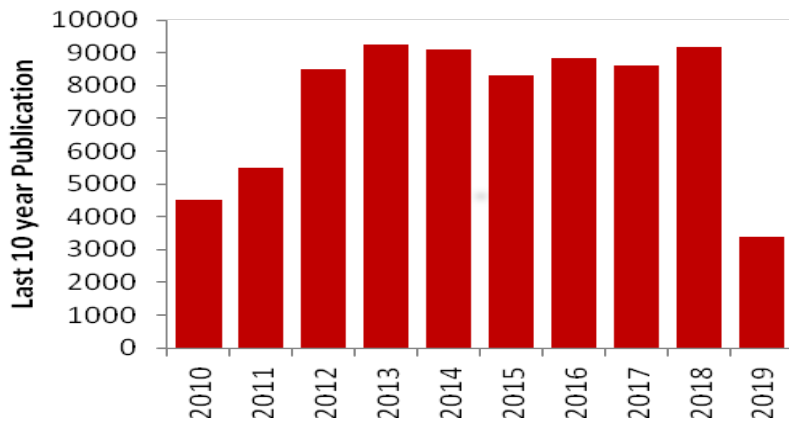

Figure 2. Number of Wireless Sensor Network based article publications by the year.

\subsection{Evaluation Matrices for WSN System}

In a WSN, there are various parameters used to estimate the throughput of the network. Numerous parameters are as follows.

\section{Network strength}

Power consumption by a sensor node in a network is the main issue. To enlarge the lifetime of a WSN network, to manage the energy utilization in a network, the network should be designed such that the sensor node consumes the least energy and transfers more data. The sensor node is either identical or odd.

\section{Scalability}

Scalability is the property of a wireless system to handle the performance of a network by adding resources (sensor node) to the wireless network system. Suppose new nodes are added to the network, and then there will be no effect on any output of the network.

\section{Temporal accuracy}

The sensor nodes of WSN send the sensed information from time to time to the end-user to take a decision for betterment. Every operation performs within a specific period of time.

\section{Coverage}

Coverage in a wireless sensor network means to sense over the target region. This is a primary factor for ensuring the eminence of examination provided by the WSNs or in another way we can say that all sensor nodes are dispersed in the whole region to be observed.

\section{Response time}

Any type of wireless sensor network-based application, an application that has a good response time for fire detection scenario response time should be fast with respect to the sensor node. If the sensor node is in an active mode they provide the information quickly when a fire is found.

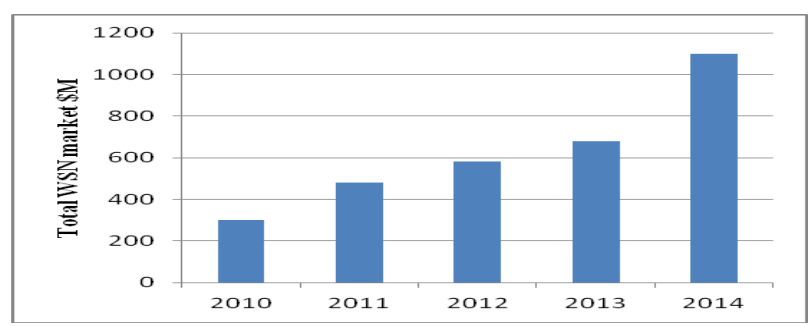

Figure 3. WSN market 2010-2014 (\$ Millions)[19]

\section{Security}

Security is an important factor in wireless sensor networks. Threats do not allow entering the application and disturbed the application processes a sensor node deployed in a remote or hostile environment and perform their task in an unattended manner. WSN application 
prevents the attack from outside and secures the privacy of collected data.

\subsection{Clustering and $\mathrm{CHs}$ Election}

Clustering is one of the energy maximize technique used to increase network lifespan in WSN. These include grouping device nodes for clusters and choosing $\mathrm{CHs}$ for all clusters. Cluster heads collect the information that is sent by the sensor node, and then the cloister head chooses the shortest route to pass the collected information to the sink. Clustering and choosing a cluster head are both very important approaches that can be used to increase the lifetime of the WSN.

\subsubsection{Cluster Component}

There are various important cluster components are listed as follows:

- Cluster member

- Cluster head $(\mathrm{CH})$

- Gateway node

- Intra-cluster link

- Cross-cluster link

\subsubsection{Cluster Head}

$\mathrm{CH}$ plays a significant role to broadcast the message to the sink and they also do data fusion and data aggregation. Apart from $\mathrm{CH}$, all node acts as a non- $\mathrm{CH}$ or cluster member. The main challenge in WSNs is to elect the cluster heads on the basis of some input parameter some common parameter used to elect the $\mathrm{CHs}$ are as follows:

- Remaining energy

- Number of neighbors nodes

- Farness from sink to nodes

\subsubsection{Clustering Objectives}

In the cluster technique, there are some objective cluster listed as follows [20]:

- Aggregations allow

- Limits data transmission

- Enhanced network lifetime

- Diminish network traffic

- Data fusion takes place in cluster heads

- Minimize coverage problem

\subsubsection{Advantages of Clustering}

- Scalability

- Data aggregation

- Fewer loads

- Minimization of energy utilization

- Minimize the Collision between sensor nodes

- Load Balancing

- To avoid Fault tolerance

\section{- Improve the QoS}

\subsubsection{Classification of Cluster Based Protocol}

There are various parameter used in different types protocol. LEACH protocol is one of them and there are numerous variant of LEACH protocol shown in the table. Figure 4 shows that the over view of modified LEACH based protocols according to the classification they are depict here only because of all these technique use to decrease the complexity of the network.

\section{- $\quad$ Election of $\mathrm{CH}$}

The selection of $\mathrm{CH}$ in any clustering algorithm is a significant task to conserve the energy of $\mathrm{SN}$ and to extend the lifetime of WSN. Figure 5 shows the observations for choosing $\mathrm{CH}$ based on the criteria given below.

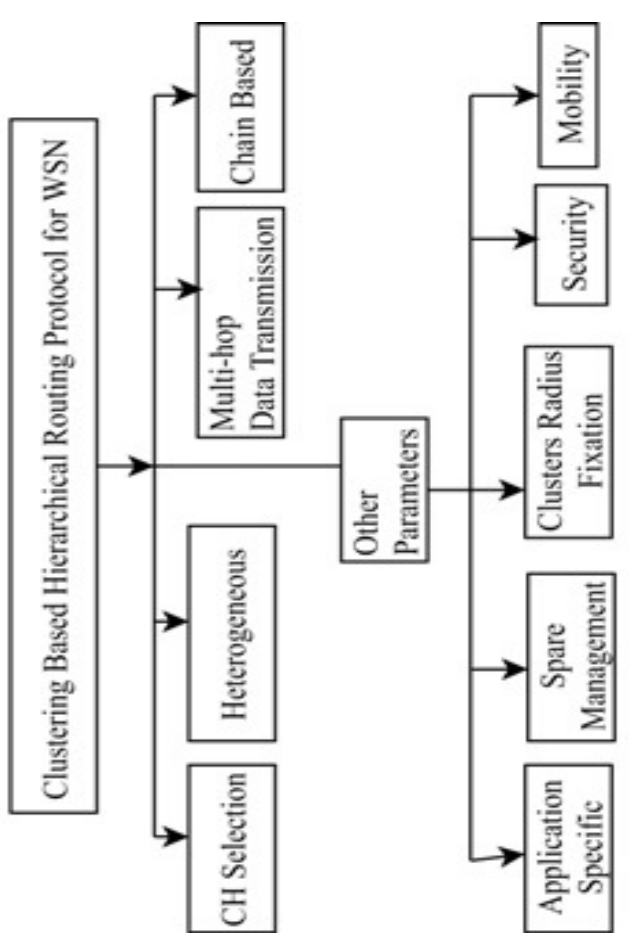

Figure 4. Numerous techniques related to routing protocol of WSN

$\mathrm{CH}$ selection uses different parameter as an input for the fuzzy system and produces an output to solve the uncertainty of a WSN in terms of energy. Fig. 5 shows in detail the various protocols related to $\mathrm{CH}$ selection and the benefit of clustering is: reduces energy utilization by maximizing bandwidth utilization, minimize overhead, maximum connectivity established, reduce delay in data transmission, load balancing, reduce the size of the routing table, and stabilized network topology. The organization of this review paper is as follows. The fuzzybased system described in Section II, literature review of energy-aware routing protocol with clustering method, 
merit and limitation discuss in Section III, Fuzzy based clustering protocol are given in Section IV, comparison of the various novel fuzzy-based protocol with their lifetime discuss in Section $\mathrm{V}$ and in Section VI describe the conclusion and future direction of this review paper.

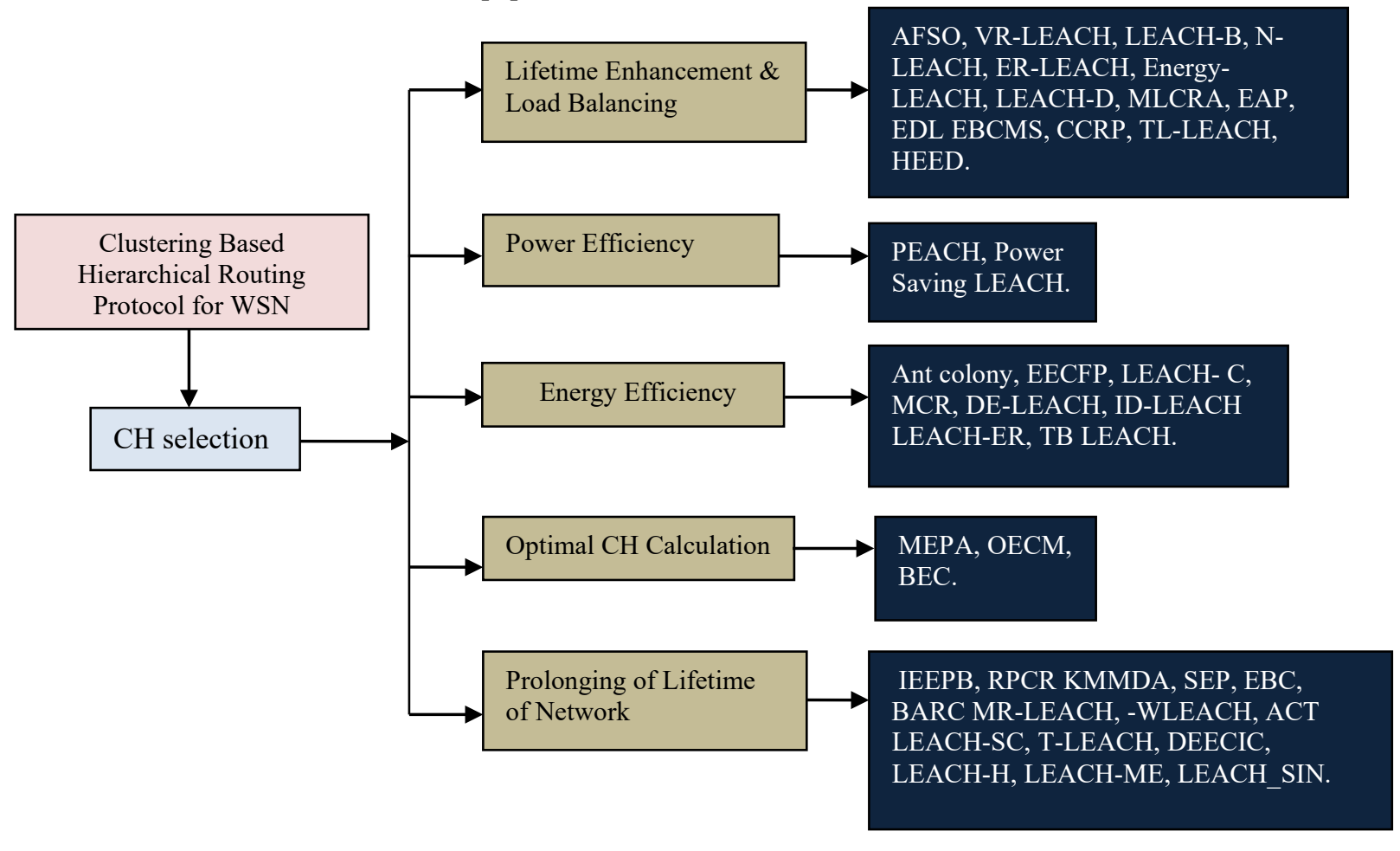

Figure 5. Multiple cluster head selection scheme and their protocol

\section{Fuzzy Logic}

The problem of uncertainty handles by fuzzy logic. Uncertainty arises when cluster are formed and on the basis of variable when select cluster head. Fuzzy play a very important role to select the cluster head [14] in WSNs [21] . Fuzzy input working with predefines set of rule. It maps input space into output space. The membership function of a fuzzy logic requires expert knowledge and creates a set of rules to draw a conclusion from the given data. The membership function may give different values for the same set of rules of the fuzzy logic system. System design requires initial knowledge to select a membership function. Figure 6 indicates that the working version of a fuzzy logic device wherein enter facts is fuzzified into some of the fuzzy sets and then in line with the predefined set of rule inference drawn from the input fuzzy units. Defuzzifier converts the fuzzy sets into a crisp value for the $\mathrm{CH}$ selection chance calculated by the output of the crisp value of FIS. In WSN, fuzzy logic systems are used to deal with many issues such as decision-making uncertainty, routing, and network security.

\section{Literature Review}

In this segment, a literature review is presented in the form of table1 and various fuzzy based clustering protocol and methods are briefly reviewed.

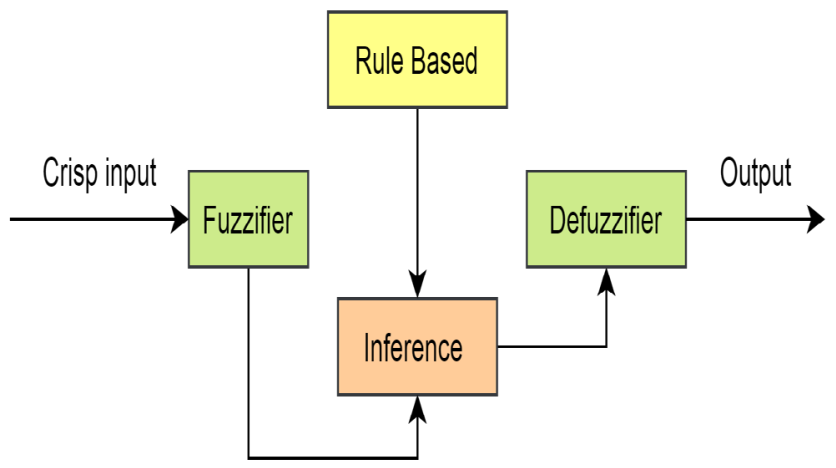

Figure 6. Fuzzy Logic System

\section{Fuzzy-Based Clustering Protocol}

Fuzzy based algorithms help in enhancing the performance of WSN have been given here. All describe protocol is come into the existence after 2010. All are energy efficient and they are very much helpful to maximize the life span of WSN. 
Table 1. Literature Review

\begin{tabular}{|c|c|c|c|c|}
\hline Author & Technique & $\begin{array}{c}\text { Clustering } \\
\text { Method }\end{array}$ & Advantage & Limitation \\
\hline $\begin{array}{l}\text { Gupta et.al[14] } \\
\quad(2005)\end{array}$ & $\begin{array}{l}\text { Election of CH } \\
\text { based on fuzzy } \\
\text { logic }\end{array}$ & $\begin{array}{l}\text { Centralized } \\
\text { clustering approach } \\
\text { and chance to } \\
\text { become CHs } \\
\text { calculated by using } \\
\text { fuzzy logic. } \\
\end{array}$ & $\begin{array}{l}\text { i) Homogeneously } \\
\text { allotment of CHs in } \\
\text { clustered area. } \\
\text { ii) More well-organized } \\
\text { than LEACH. }\end{array}$ & $\begin{array}{l}\text { i) Use for tiny } \\
\text { Scale Network. } \\
\text { ii) Sink control network } \\
\text { Periodically. }\end{array}$ \\
\hline $\begin{array}{l}\text { Kim et al[ }[22] . \\
\quad(2008)\end{array}$ & $\begin{array}{l}\text { Novel fuzzy based } \\
\text { clustering. }\end{array}$ & $\begin{array}{l}\text { Blender of LEACH } \\
\text { and fuzzy logic. }\end{array}$ & $\begin{array}{l}\text { i) Dynamic clustering } \\
\text { ii) All the assessment taken } \\
\text { at node level. } \\
\text { iii) Application for big } \\
\text { scale network. }\end{array}$ & $\begin{array}{l}\text { i) The distribution of } \mathrm{CHs} \\
\text { is Non deterministic. } \\
\text { ii) cluster radius limitation } \\
\text { for } \mathrm{CHs} \text {. }\end{array}$ \\
\hline $\begin{array}{l}\text { Tashtoush et. } \\
\text { al[23] (2008) }\end{array}$ & $\begin{array}{l}\text { Fuzzy self- Cluster } \\
\text { Algorithm used. }\end{array}$ & $\begin{array}{l}\text { CHs selection, } \\
\text { cluster formation } \\
\text { based on the output } \\
\text { of fuzzy system. }\end{array}$ & $\begin{array}{l}\text { i) Sensor location } \\
\text { information not required } \\
\text { before. } \\
\text { ii) Select Remaining } \\
\text { energy for } \mathrm{CH} \\
\text { selection. }\end{array}$ & $\begin{array}{l}\text { i) Immigration of cluster is } \\
\text { only applicable in partial } \\
\text { applications. } \\
\text { ii) Required maximum time } \\
\text { to run the protocol. }\end{array}$ \\
\hline $\begin{array}{l}\text { Haider et. al[24] } \\
\text { (2009) }\end{array}$ & $\begin{array}{l}\text { Energy optimization } \\
\text { using Fuzzy } \\
\text { approach. }\end{array}$ & $\begin{array}{l}\text { Primarily determined } \\
\text { routing quite than } \\
\text { the clustering. }\end{array}$ & $\begin{array}{l}\text { i) Enhanced the life span } \\
\text { of senor network. } \\
\text { ii) Balance routing } \\
\text { Load between sensors } \\
\text { According to node } \\
\text { Fuzzy production. }\end{array}$ & $\begin{array}{l}\text { i) In fuzzy logic system } \\
\text { used Six input variable. } \\
\text { ii) Clustering is not } \\
\text { used. } \\
\text { iii) Use gateway for all } \\
\text { decision in network. }\end{array}$ \\
\hline $\begin{array}{l}\text { Raghuvan } \\
\text { shi et al.[25] } \\
\text { (2010) }\end{array}$ & $\begin{array}{l}\text { Use fuzzy c-means } \\
\text { (FCM) clustering } \\
\text { technique. }\end{array}$ & $\begin{array}{l}\text { Clustering perform } \\
\text { in WSN with the } \\
\text { help of natural } \\
\text { grouping of data set. }\end{array}$ & $\begin{array}{l}\text { i) Same as unsupervised } \\
\text { learning algorithm. } \\
\text { ii) Detect sensor Related } \\
\text { with To find other } \\
\text { groups Out of overlap } \\
\text { Between groups } \\
\text { Correction of fault } \\
\text { Tolerance. }\end{array}$ & $\begin{array}{l}\text { i) FCM application is } \\
\text { Limited in case of WSN } \\
\text { ii) In c- mean clustering } \\
\text { sensor are limited in } \\
\text { calculation and May } \\
\text { increase message overheads. }\end{array}$ \\
\hline $\begin{array}{l}\text { Ran et al.[26] } \\
\text { (2010) }\end{array}$ & LEACH-FL & $\begin{array}{l}\text { Possibility to } \mathrm{CH} \\
\text { election and } \\
\text { formation based on } \\
\text { fuzzy logic. }\end{array}$ & $\begin{array}{l}\text { i) Performance of this } \\
\text { protocol is better than } \\
\text { traditional. } \\
\text { ii) Minimize uncertainty in } \\
\text { decision making } \\
\text { about CH using } \\
\text { Fuzzy logic. }\end{array}$ & $\begin{array}{l}\text { i) Clustering is centralized. } \\
\text { ii) Input variable same as } \\
\text { apply to Gupta approach. } \\
\text { iii) Same problem in Gupta } \\
\text { approach. }\end{array}$ \\
\hline $\begin{array}{l}\text { Taheri et al.[27] } \\
(2010)\end{array}$ & HEED-NPF & $\begin{array}{l}\text { Using fuzzy logic } \\
\text { HEED protocol } \\
\text { further improved. }\end{array}$ & $\begin{array}{l}\text { i) Remaining energy play } \\
\text { an important role for } \mathrm{CH} \\
\text { selection. } \\
\text { ii) The efficiency of HEED } \\
\text {-NPF is } 20 \text { percent more } \\
\text { than the HEED. }\end{array}$ & $\begin{array}{l}\text { i) Hot-Spot problem. } \\
\text { ii) Number of CHs is } \\
\text { fixed. }\end{array}$ \\
\hline
\end{tabular}




\begin{tabular}{|c|c|c|c|c|}
\hline $\begin{array}{l}\text { Saeedian et } \\
\text { al.[28] (2011) }\end{array}$ & $\begin{array}{l}\text { Genetic algorithm } \\
\text { (CFGA) and fuzzy } \\
\text { logic used for } \\
\text { Clustering in WSN. }\end{array}$ & $\begin{array}{l}\text { Multi-hop } \\
\text { centralized } \\
\text { clustering technique. }\end{array}$ & $\begin{array}{l}\text { i) Used genetic algorithm } \\
\text { and centralized clustering } \\
\text { approach for CHs } \\
\text { distribution in WSN. } \\
\text { ii) Sink is located within } \\
\text { the region then network } \\
\text { work efficiently. }\end{array}$ & $\begin{array}{l}\text { i) Only used for tiny } \\
\text { scale networks. } \\
\text { ii) Used only Centralized } \\
\text { clustering. }\end{array}$ \\
\hline $\begin{array}{l}\text { Jin et } \\
\text { al. }[8](2011)\end{array}$ & $\begin{array}{l}\text { Apply fuzzy } \\
\text { inference system in } \\
\text { WSNs for clustering } \\
\text { routing protocol } \\
(\mathrm{CEFM}) \text {. }\end{array}$ & $\begin{array}{l}\text { Similar to the } \\
\text { LEACH protocol. } \\
\text { Cluster formation } \\
\text { performs based on } \\
\text { novel parameter. }\end{array}$ & $\begin{array}{l}\text { i) Applying dynamic } \\
\text { clustering. } \\
\text { ii) A novel input parameter } \\
\text { data retransmission rate } \\
\text { used. } \\
\text { iii) The throughput of this } \\
\text { network is better as } \\
\text { contrast to LEACH } \\
\text { protocol. }\end{array}$ & $\begin{array}{l}\text { i) } \mathrm{CH} \text { selection and failure } \\
\text { issue are not considering in } \\
\text { this protocol. }\end{array}$ \\
\hline $\begin{array}{l}\text { Pires et } \\
\text { al.[29](2011) }\end{array}$ & $\begin{array}{l}\text { CHs election based } \\
\text { on type - } 2 \text { fuzzy } \\
\text { systems (CHEATS). }\end{array}$ & $\begin{array}{l}\text { Cluster formation } \\
\text { based on fuzzy } \\
\text { inference system-2. }\end{array}$ & $\begin{array}{l}\text { i) Used Mamdani model to } \\
\text { solve the Uncertainty in } \\
\mathrm{CH} \text { selection. } \\
\text { ii) Clustering perform in } \\
\text { next level of algorithms. }\end{array}$ & $\begin{array}{l}\text { i) Enhancement of this } \\
\text { protocol is less as } \\
\text { compare to LEACH } \\
\text { protocol. } \\
\text { ii) CH failure } \\
\text { problem not addressed. } \\
\text { iii) CHs distribution } \\
\text { In Non uniform manner. }\end{array}$ \\
\hline $\begin{array}{l}\text { Shen and Ju et } \\
\text { al.[30] (2011) }\end{array}$ & $\begin{array}{l}\text { Clustering apply in } \\
\text { heterogeneous } \\
\text { WSN. }\end{array}$ & $\begin{array}{l}\text { like to CHEF } \\
\text { protocol for cluster } \\
\text { formation. }\end{array}$ & $\begin{array}{l}\text { i) Same virtues as CHEF } \\
\text { protocol. }\end{array}$ & $\begin{array}{l}\text { i) Heterogeneity is problem } \\
\text { in this protocol. }\end{array}$ \\
\hline $\begin{array}{l}\text { Siew et } \\
\text { al.[31](2011) }\end{array}$ & $\begin{array}{l}\text { Fuzzy based } \\
\text { clustering used in } \\
\text { this protocol. }\end{array}$ & $\begin{array}{l}\text { Same as Gupta } \\
\text { approach. }\end{array}$ & $\begin{array}{l}\text { i) Parameter used same as } \\
\text { Gupta et al. }\end{array}$ & $\begin{array}{l}\text { i) Similar problem to } \\
\text { Gupta's approach. }\end{array}$ \\
\hline $\begin{array}{l}\text { Ben el } \\
\text { at.[32](2012) }\end{array}$ & $\begin{array}{l}\text { CHs and Gateway } \\
\text { selection using } \\
\text { fuzzy logic systems. }\end{array}$ & $\begin{array}{l}\text { Two tiers } \\
\text { hierarchical } \\
\text { clustering approach } \\
\text { apply. }\end{array}$ & $\begin{array}{l}\text { i) Load distribution of } \mathrm{CHs} \\
\text { again distributed with } \\
\text { respect to gateways. } \\
\text { ii) Minimize energy } \\
\text { utilization of CHs. } \\
\text { iii) Multi-hop } \\
\text { communication }\end{array}$ & $\begin{array}{l}\text { i) Network collapse If } \\
\text { gateway fails. } \\
\text { ii) Hotspot problem arises } \\
\text { if Gateway near to sink. } \\
\text { iii) More overheads in } \\
\text { WSN. }\end{array}$ \\
\hline $\begin{array}{l}\text { Mhemed et al. } \\
{[33](2012)}\end{array}$ & $\begin{array}{l}\text { A FLCEP protocol } \\
\text { was proposed for } \\
\text { cluster formation in } \\
\text { WSN. }\end{array}$ & $\begin{array}{l}\text { Cluster formation } \\
\text { clustering Based on } \\
\text { fuzzy output value. }\end{array}$ & $\begin{array}{l}\text { i) A novel parameter use to } \\
\text { Cluster formation. } \\
\text { ii) The energy utilization } \\
\text { is minimum of Cluster } \\
\text { members within the } \\
\text { cluster. }\end{array}$ & $\begin{array}{l}\text { i) Energy utilization } \\
\text { of } \mathrm{CH} \text { is not minimized } \\
\text { only reduces the energy } \\
\text { consumption of cluster } \\
\text { member. } \\
\text { ii) } \mathrm{CH} \text { distribution Not } \\
\text { uniform like LEACH. }\end{array}$ \\
\hline $\begin{array}{l}\text { Mao et } \\
\text { al. }[5](2012)\end{array}$ & $\begin{array}{l}\text { Enhanced fuzzy } \\
\text { unequal clustering } \\
\text { (IFUC). }\end{array}$ & $\begin{array}{l}\text { Clustering perform } \\
\text { with the help of Ant } \\
\text { Colony Optimization } \\
\text { (ACO) technique. }\end{array}$ & $\begin{array}{l}\text { i) Minimize hot spots } \\
\text { problem in WSN. } \\
\text { ii) Energy utilization of } \\
\text { CHs is equal for large } \\
\text { scale network. }\end{array}$ & $\begin{array}{l}\text { i) More CHs are required } \\
\text { but due to enabled cluster } \\
\text { Radius it can't possible. } \\
\text { ii) Cluster formation need } \\
\text { large amount of } \\
\text { information exchanged in } \\
\text { WSN. }\end{array}$ \\
\hline $\begin{array}{l}\text { Izadi et al.[34] } \\
(2013)\end{array}$ & $\begin{array}{l}\text { SCCH protocol } \\
\text { proposed for Self- }\end{array}$ & $\begin{array}{l}\text { The role of } \mathrm{CH} \\
\text { change based on left }\end{array}$ & $\begin{array}{l}\text { i) CHs are consistently } \\
\text { Dispersed due to cluster }\end{array}$ & $\begin{array}{l}\text { i) Cluster formation is static } \\
\text { and number of cluster }\end{array}$ \\
\hline
\end{tabular}




\begin{tabular}{|c|c|c|c|c|}
\hline & $\begin{array}{l}\text { configured } \mathrm{CH} \\
\text { selection. }\end{array}$ & $\begin{array}{l}\text { over energy of a } \\
\text { sensor node after } \\
\text { cluster formation, } \\
\text { backup CH problem } \\
\text { is addressed. }\end{array}$ & $\begin{array}{l}\text { radius. } \\
\text { ii) Easy to execute. } \\
\text { iii) Lifetime of WSNs } \\
\text { enhanced. }\end{array}$ & $\begin{array}{l}\text { member is different in } \\
\text { each cluster. } \\
\text { ii) Not focused on routing } \\
\text { clustering only focused on } \\
\text { cluster head. }\end{array}$ \\
\hline $\begin{array}{l}\text { Zhang et al.[29] } \\
\text { (2013) }\end{array}$ & $\begin{array}{l}\text { Used Type-2 fuzzy } \\
\text { logic system } \\
\text { (takagi-Sugeno- } \\
\text { Kang) for WSN. }\end{array}$ & $\begin{array}{l}\text { For clustering used } \\
\text { type-2fuzzy logic } \\
\text { system and } \\
\text { centralized method. }\end{array}$ & $\begin{array}{l}\text { i) Uncertainty is very less } \\
\text { for } \mathrm{CH} \text { election compare } \\
\text { to type-1 fuzzy } \\
\text { clustering techniques. } \\
\text { ii) CHs are additional } \\
\text { consistent } \\
\text { and balanced. }\end{array}$ & $\begin{array}{l}\text { i) Fuzzy system is } \\
\text { difficult to implement and } \\
\text { required extra time to } \\
\text { implement as compare to } \\
\text { Type-1 systems. }\end{array}$ \\
\hline $\begin{array}{l}\text { Afifi and Hefny } \\
{[35](2014)}\end{array}$ & $\begin{array}{l}\text { Design ATSFMSN } \\
\text { protocol for } \\
\text { Clustering and } \\
\text { routing technique. }\end{array}$ & $\begin{array}{l}\text { Sugeno model used } \\
\text { for clustering. }\end{array}$ & $\begin{array}{l}\text { i) Minimize the routing } \\
\text { issue. } \\
\text { ii) Clusters are consistent } \\
\text { in the network. } \\
\text { iii) It is a better approach } \\
\text { than Mamdani model. }\end{array}$ & $\begin{array}{l}\text { i) CH collapse problem } \\
\text { not measured. } \\
\text { ii) type- } 2 \text { fuzzy model is } \\
\text { difficult as compare to the } \\
\text { Mamdani model. } \\
\text { iii) Hot spots problem. }\end{array}$ \\
\hline $\begin{array}{l}\text { Natarajan and } \\
\text { Selvaraj } \\
{[36](2014)}\end{array}$ & $\begin{array}{l}\text { Apply a new } \\
\text { approach to } \\
\text { predictive Fuzzy } \\
\text { based CH election } \\
\text { algorithm. }\end{array}$ & $\begin{array}{l}\text { Clustering perform } \\
\text { the past history of } \\
\text { each node, with the } \\
\text { respective CHs. }\end{array}$ & $\begin{array}{l}\text { i) stability the energy } \\
\text { utilization within } \\
\text { Cluster. } \\
\text { ii) New parameter use to } \\
\text { increase the network } \\
\text { performance. }\end{array}$ & $\begin{array}{l}\text { i) Require of handshaking } \\
\text { information among nodes } \\
\text { that directly affects energy } \\
\text { utilization. }\end{array}$ \\
\hline $\begin{array}{l}\text { Wang et } \\
\text { al.[37](2014) }\end{array}$ & $\begin{array}{l}\text { Various parameter } \\
\text { uses to increase the } \\
\text { throughput of WSN. }\end{array}$ & $\begin{array}{l}\text { Identify the outcome } \\
\text { of various } \\
\text { parameters on } \\
\text { network lifetime } \\
\text { using fuzzy logic } \\
\text { and then cluster } \\
\text { formation was } \\
\text { performed. }\end{array}$ & $\begin{array}{l}\text { i) Remaining Battery } \\
\text { Power (RBP) of sensor } \\
\text { node have not exhaust an } \\
\text { easily. } \\
\text { ii) Sensor die earlier } \\
\text { because they will spend } \\
\text { more energy in WSN but } \\
\text { Transmission time rate } \\
\text { increases. }\end{array}$ & $\begin{array}{l}\text { i) limited input parameter } \\
\text { used. } \\
\text { ii) the overall complexity of } \\
\text { the protocol is not good in } \\
\text { terms of data transmission } \\
\text { and cluster formation. }\end{array}$ \\
\hline $\begin{array}{l}\text { Zhang et al.[38] } \\
(2014)\end{array}$ & $\begin{array}{l}\text { CRT2FLACO } \\
\text { routine protocol } \\
\text { used for WSN } \\
\text { based on type-2 } \\
\text { fuzzy logic. } \\
\end{array}$ & $\begin{array}{l}\text { Apply fuzzy based } \\
\text { unequal clustering } \\
\text { algorithm for WSN. }\end{array}$ & $\begin{array}{l}\text { i) Reduce uncertainty type- } \\
2 \text { fuzzy system used. } \\
\text { ii) for routing apply } \\
\text { Implement a optimization } \\
\text { algorithms. }\end{array}$ & $\begin{array}{l}\text { i) Energy consumption is } \\
\text { high of sensor node in } \\
\text { WSN. } \\
\text { ii) Dead of nodes earlier as } \\
\text { compare to LEACH. }\end{array}$ \\
\hline $\begin{array}{l}\text { Rana et } \\
\text { al.[39](2015) }\end{array}$ & $\begin{array}{l}\text { Motivated from } \\
\text { Gupta's approach. }\end{array}$ & $\begin{array}{l}\text { Input variable is } \\
\text { more as compare to } \\
\text { Gupta's approach the } \\
\text { rest is similar to the } \\
\text { Gupta approach. }\end{array}$ & $\begin{array}{l}\text { i) Similar to Gupta } \\
\text { approach. }\end{array}$ & $\begin{array}{l}\text { i) Use for tiny Scale } \\
\text { Network. } \\
\text { ii) Sink control network } \\
\text { Periodically. }\end{array}$ \\
\hline $\begin{array}{l}\text { Alami and } \\
\text { Najid et.al[40] } \\
(2016)\end{array}$ & $\begin{array}{l}\text { It's an extension of } \\
\text { LEACH and } \\
\text { LEACH-ERE } \\
\text { approach. }\end{array}$ & $\begin{array}{l}\text { Used a novel routing } \\
\text { approach for } \\
\text { clustering and } \mathrm{CH} \\
\text { selection. }\end{array}$ & $\begin{array}{l}\text { i) } \mathrm{CH} \text { is selected when the } \\
\text { node near to sink. } \\
\text { ii) Dynamic clustering. }\end{array}$ & $\begin{array}{l}\text { i) Residual energy not } \\
\text { calculated of each sensor. } \\
\text { ii) CHs focus in meticulous } \\
\text { area like LEACH. }\end{array}$ \\
\hline $\begin{array}{l}\text { Homayun et } \\
\text { al.[41] (2017) }\end{array}$ & $\begin{array}{l}\text { CHs selection using } \\
\text { fuzzy logic. }\end{array}$ & $\begin{array}{l}\text { Novel energy- } \\
\text { enhance clustering } \\
\text { method with three } \\
\text { input parameter. }\end{array}$ & $\begin{array}{l}\text { i) Most suitable cluster } \\
\text { head selected based on } \\
\text { threshold. } \\
\text { ii) Dynamic clustering. }\end{array}$ & $\begin{array}{l}\text { i) Maximum number of } \\
\text { information exchanged } \\
\text { For formation of cluster } \\
\text { take maximum time. } \\
\text { ii) Maximum input } \\
\text { parameter take a maximum } \\
\text { time. }\end{array}$ \\
\hline Mehra et al. & Zonal based & Clustering apply on & i) Enhance network life & i) Lacks of cluster formation \\
\hline
\end{tabular}




\begin{tabular}{|l|l|l|l|l|}
\hline [42](2018) & clustering. & each zone & $\begin{array}{l}\text { time due to zonal } \\
\text { based approach. } \\
\text { ii) Enhance the stability } \\
\text { period of network also. }\end{array}$ & algorithms. \\
\hline $\begin{array}{l}\text { Aziz Mahboub } \\
\text { etal.[43](2019) }\end{array}$ & $\begin{array}{l}\text { Clustering based on } \\
\text { Stable Election } \\
\text { Protocol. }\end{array}$ & $\begin{array}{l}\text { Centralized } \\
\text { clustering performs } \\
\text { at their initial } \\
\text { locations. }\end{array}$ & $\begin{array}{l}\text { i) Dynamic clustering. } \\
\text { ii) New selection } \\
\text { parameters criteria enhance } \\
\text { the performance of WSN. }\end{array}$ & $\begin{array}{l}\text { i) CHs are selected } \\
\text { randomly. }\end{array}$ \\
ii) Hot spots problem.
\end{tabular}

of the CHEF algorithm. It has a better performance than

\section{Novel approach for $\mathrm{CH}$ election[14]}

Novel approach (Gupta et al., 2005) is one of the methods for $\mathrm{CH}$ election. The algorithm basically consists of two phases. In the first phase, the sink calculates the chance value which includes concentration, energy and centrality of each of the sensor node along with some other information in order to choose the $\mathrm{CH}$ candidate. In the second stage, each of the $\mathrm{CH}$ conspired about the time schedule and grouping of data. The algorithm and flowchart are given in the below figure $3 \& 4$. This stage of the algorithm performs recursively and thus uniformly distributes the load in the network. This algorithm also helps in enhancing the lifetime of the network. But along with these all benefits, the algorithm has the following disadvantages, Sink periodically collects information which increases the pressure on the sink, not any look over the $\mathrm{CH}$ failure, more energy required, used for small scale network and at last only one cluster head selected using this approach.

\section{CHEATS [44] protocol}

It is also called a Takagi-Sugeno fuzzy system for $\mathrm{CH}$ selection, described in Pires et al. (2011). CHEATS has a $10 \%$ upgrade over LEACH. CHEATS uses the Sugeno model for $\mathrm{CH}$ selection and uses only two boundary variables i.e. sensor node distance to its sink \& leftover energy of nodes. It is somehow better than LEACH but it also not overcome some of the challenges including network heterogeneity failure of $\mathrm{CH} \&$ selection of most appropriate $\mathrm{CH}$ for the network.

\section{CHEF[45] protocol}

Like LEACH protocol, it also formed the cluster in every round \& using the energy and local farness as the variables it uses the fuzzy output in order to select the $\mathrm{CH}$. Figure 6 represents the flowchart \& figure 5 depicts the pseudo-code
LEACH. If two sensor nodes have the same chance value to become $\mathrm{CH}$ then this algorithm has not the appropriate Procedure to find which one is better for $\mathrm{CH}$. IF one end of the $\mathrm{n} / \mathrm{w}$ has a high concentration of $\mathrm{CH}$ then as per cluster radius condition the number of $\mathrm{CH}$ is reduced and hence increases the chance of $\mathrm{CH}$ failure. It somehow overcomes the limitation of a novel approach for $\mathrm{CH}$ election.

\section{FBECS [46] protocol}

FBECS for wireless sensor network uses the fuzzy interference system that uses the residue energy, density of a node to its neighbor's node and distance of node to sink and then calculate the 'Eligibility Index' in order to select the suitable cluster head among all the sensor node.

It proves to be better than LEACH \& BCSA protocol. It provides the load balancing, extended lifetime of network and also delivered wide-ranging information to the sink.

\section{FLEACH[47] protocol}

The formation of cluster in WSN should always be performed in such a way that it should lower energy utilization. Various methods are evolved to reduce energy consumption during formation of cluster, but they all proved to be expensive. This paper describes the FLEEC protocol with two phases and made for optimizing energy utilization. In the first stage of this algorithm, the sink node uses the following two fuzzy inputs as Node-density \& distance to sink in order to find the communication radius for all the sensor nodes. The second stage uses the residual energy and total distance obtained in the first level in order to determine the chances of being $\mathrm{CH}$. Experimentally proved that this protocol is better than LEACH \& EFCH in term of utilizing the energy carefully.

\section{CHUFL[40] protocol}

The $\mathrm{CH}$ selection protocol CHUFL is one of another algorithm for cluster head selection. The $\mathrm{CH}$ selection using 
this algorithm is based on some attribute including a communication link between nodes, surplus energy of the nodes, farness between the neighbor sensor nodes, distance between the sensor nodes \& sink. CHUFL is relaxed up to $20 \%$ in energy consumption as compared to CHEF by Kim et al. \& cluster head selection method for WSN by J. Anno et al. and CHUFL also sends information from the sensor node to sink up to $72 \%$ more in contrast with J. Anno et al. protocol.

\section{SCHFTL[48] protocol}

One of the prominent challenges in the WSN is to minimize energy consumption $\&$ this can be achieved by choosing the appropriate method for $\mathrm{CH}$ selection. One such algorithm is the LEACH algorithm which selects the $\mathrm{CH}$ on the basis of some threshold value. In the LEACH algorithm the sensor node transmits the data to their $\mathrm{CH}$ and $\mathrm{CH}$ collectively transmits the data to sink. This protocol describes another protocol called SCHFTL . This algorithm chooses the super cluster head among all the available $\mathrm{CHs}$ with the help of Mamdani interference engine. It is more productive than FMCHEL fuzzy based master $\mathrm{CH}$ election leach \& $\mathrm{CHEF}$ protocol.

\section{E-CAFL[49] protocol}

In WSN, the sensor nodes are grouped to form a cluster \& each of the sensor nodes transmits information to their $\mathrm{CH}$. The $\mathrm{CH}$ finally transmits this information to the sink. The $\mathrm{CH}$ plays a vital role in this overall process, so the method of choosing the $\mathrm{CH}$ is most important because due to any variance in consumption of energy by the sensor node, the overall network gets failure. This paper introduces one of the algorithms that select the desirable $\mathrm{CH}$ called E-CAFL. This algorithm is the advanced form of CAFL algorithm. This algorithm calculates the rank of each sensor nodes using the fuzzy interference system and leftover energy, distance between node to sink \& node density are the fuzzy input to the system. This algorithm is more desirable over the CAFL \& LEACH algorithm in term of both the network lifetime as well as performance.

\section{MOFCA[50] protocol}

Clustering is the well-organized method in WSN. If not only gathered the information from its nearby cluster nodes but also very much efficient in terms of energy utilization. In the multi hop environment of the WSN information is transmitted from one $\mathrm{CH}$ to another $\mathrm{CH}$ until it reaches to the sink. In this method of transmission the $\mathrm{CH}$ which is near to the sink gets die due to sense inter cluster transmission. This situation is called the hotspot problem in WSN. This hotspot problem can be somehow solved by using the unequal clustering approach in which the cluster size reduces as it goes nearer to the sink. Along with the hotspot problem, another problem that occurs in the WSN is the energy hole problem which occurs due to variance in the position of the sensor node distribution. MOFCA protocol is used to solve the hotspot \& energy hole problem. Some experiments are done using efficiency metrics like First Node Dies (FND), half of the Node Alive (HNA) and Total Remaining Energy (TRE) shows that MOFCA perform better as compared to few traditional protocols.

\section{FUCA[51]protocol}

Unequal clustering is also performed to improve the life span of the WSN. In case of the unequal clustering the sizes of clusters are getting reduces and reach closer to the sink. This fuzzy based unequal clustering algorithm also uses the unequal clustering concept which evenly distributes the consumption of energy. This algorithm uses the leftover energy, density of the nodes \& farness of sensor node to its sink as the fuzzy $\mathrm{i} / \mathrm{p}$ and competition radius \& rank as fuzzy output. Mamdani method \& the fuzzy logic concept used here for $\mathrm{CH}$ selection. This algorithm proved more desirable and improved version in terms of both performance and network lifetime as compared to $\mathrm{LEACH}$, and another energy-aware unequal clustering fuzzy based protocol.

\section{Comparison}

In this segment, various clustering methods based on fuzzy logic are comparing. Figure. 7 has shown the network lifetime enhancement of the latest cluster-based protocol. LEACH is a traditional protocol that is very useful to enhance the lifespan of the WSNs, apart from LEACH we have to consider the latest protocol which is more useful as compared to LEACH for WSNs.

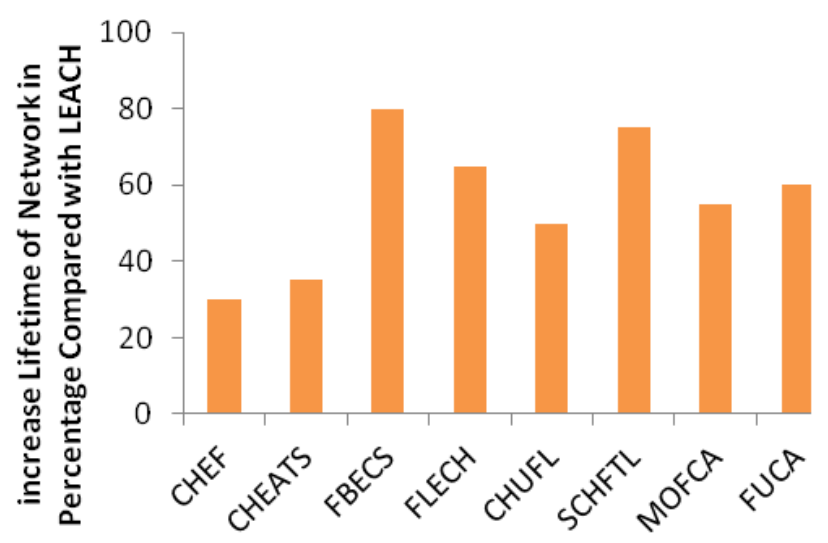

Figure 7. Lifetime in percentage as compared to various protocols. 
Basically the performance of the clustering technique based on the input parameter which is used in fuzzy logic system [52]. With the help of MATLAB, numerous algorithms are implemented with initial parameter a value which is listed in table no. 3 to evaluate the performance of WSNs in terms of FND, QND, and LND which is shown in

Table 2. Analysis of Numerous fuzzy based clustering techniques

\begin{tabular}{|c|c|c|c|c|c|}
\hline Protocol & Network type & $\begin{array}{l}\text { Clustering } \\
\text { Method }\end{array}$ & CH Election & Parameter of CH Selection & $\begin{array}{l}\text { Communication } \\
\text { Based on Inter } \\
\text { cluster }\end{array}$ \\
\hline $\begin{array}{l}\text { HEED-NPF } \\
\text { (Younis and } \\
\text { Fahmy, } \\
\text { 2004)[53] }\end{array}$ & Homogenous & scattered & Verify by Sink & $\begin{array}{ll}\text { - } & \text { Centrality } \\
\text { - } & \text { Node degree }\end{array}$ & $\begin{array}{l}\text { Multi-hop } \\
\text { communication }\end{array}$ \\
\hline $\begin{array}{l}\text { CHEF (Kim et } \\
\text { al., 2008) [7] }\end{array}$ & Homogenous & scattered & arbitrary & $\begin{array}{ll}- & \text { Energy } \\
\text { - } & \text { limited distance } \\
\end{array}$ & $\begin{array}{l}\text { Direct } \\
\text { communication }\end{array}$ \\
\hline $\begin{array}{l}\text { LEACH-FL } \\
\text { (Ran et al., } \\
\text { 2010)[26] }\end{array}$ & Homogenous & Centralized & Verify by Sink & $\begin{array}{ll} & \text { Node energy } \\
\text { - } & \text { Density } \\
\text { - } & \text { Distance from Sink }\end{array}$ & $\begin{array}{l}\text { Multi-hop } \\
\text { communication }\end{array}$ \\
\hline $\begin{array}{l}\text { CFGA } \\
\text { (Saeedian et al., } \\
\text { 2011) [28] }\end{array}$ & Homogenous & Centralized & Verify by Sink & $\begin{array}{ll} & \text { Distance } \\
\text { - } & \text { Energy } \\
\text { - } & \text { Density } \\
\end{array}$ & $\begin{array}{l}\text { Multi-hop } \\
\text { communication }\end{array}$ \\
\hline $\begin{array}{l}\text { CEFM (Jin et } \\
\text { al., 2011) [54] }\end{array}$ & Homogenous & scattered & $\begin{array}{l}\text { Determine by } \\
\text { Sink }\end{array}$ & $\begin{array}{ll}\text { - } & \text { Energy } \\
\text { - } & \text { No of neighbors } \\
\text { - } & \text { Retransmission Rate } \\
\text { - } & \text { Position } \\
\end{array}$ & $\begin{array}{l}\text { Direct } \\
\text { communication }\end{array}$ \\
\hline $\begin{array}{l}\text { CHEATS (Pires } \\
\text { et al., 2011) } \\
{[44]}\end{array}$ & Homogenous & scattered & arbitrary & $\begin{array}{ll}\text { - } & \text { Remaining energy } \\
\text { - } & \text { Distance from Sink }\end{array}$ & $\begin{array}{l}\text { Direct } \\
\text { communication }\end{array}$ \\
\hline $\begin{array}{l}\text { GCHE-FL (Ben } \\
\text { Alla et al., } \\
\text { 2012) [32] }\end{array}$ & Heterogeneous & scattered & arbitrary & $\begin{array}{l}\text { Gateway selection } \\
\text { - } \quad \text { Energy } \\
\text { - } \quad \text { closeness to Sink } \\
\text { CH Selection } \\
\text { - Efficiency } \\
\text { - } \quad \text { Cluster-distance }\end{array}$ & $\begin{array}{l}\text { Multi-hop } \\
\text { communication }\end{array}$ \\
\hline $\begin{array}{l}\text { LEACH-ERE } \\
\text { (Lee and Wang } \\
\text { et al., 2012)[8] }\end{array}$ & Homogenous & scattered & arbitrary & $\begin{array}{ll}- & \text { Remnant energy } \\
\text { - } & \text { Probable remnant } \\
\text { energy }\end{array}$ & $\begin{array}{l}\text { Direct } \\
\text { communication }\end{array}$ \\
\hline $\begin{array}{l}\text { FLCEP } \\
\text { (Mhemed et al., } \\
2012)[33]\end{array}$ & Homogenous & scattered & arbitrary & $\begin{array}{ll}\text { - } & \text { Energy level } \\
\text { - } & \text { farness between Sink } \\
& \text { and } \mathrm{CH} \\
\text { - } & \text { farness among } \mathrm{CH} \\
\end{array}$ & $\begin{array}{l}\text { Direct } \\
\text { communication }\end{array}$ \\
\hline $\begin{array}{l}\text { IFCU (Mao et } \\
\text { al., 2012) [6] }\end{array}$ & Homogenous & scattered & arbitrary & $\begin{array}{ll}- & \text { Energy level } \\
\text { - } & \text { Distance to Sink } \\
\text { - } & \text { Local density } \\
\end{array}$ & $\begin{array}{l}\text { Multi-hop } \\
\text { communication }\end{array}$ \\
\hline $\begin{array}{l}\text { HFCP (Mohan } \\
\text { et al., 2013)[55] }\end{array}$ & Heterogeneous & scattered & Random & $\begin{array}{ll}- & \text { Remnant energy } \\
\text { - } & \text { Predicted Remnant } \\
& \text { energy } \\
\end{array}$ & $\begin{array}{l}\text { Direct } \\
\text { communication }\end{array}$ \\
\hline $\begin{array}{l}\text { ICT2TSK (Zang } \\
\text { et al., 2013) [29] }\end{array}$ & Homogenous & Centralized & Verify by Sink & $\begin{array}{ll}\text { - } & \text { Residual energy } \\
\text { - } & \text { farness to sink } \\
\text { - } & \text { Total no of node } \\
& \text { around CH. } \\
\end{array}$ & $\begin{array}{l}\text { Direct } \\
\text { communication }\end{array}$ \\
\hline $\begin{array}{l}\text { ATSFMSN } \\
\text { (Afifi and Hefny } \\
\text { et al., 2014) } \\
\text { [35] }\end{array}$ & Homogenous & Centralized & Verify by Sink & $\begin{array}{l}\text { For CH election } \\
-\quad \text { Energy } \\
-\quad \text { Centrality }\end{array}$ & $\begin{array}{l}\text { Multi-hop } \\
\text { communication }\end{array}$ \\
\hline
\end{tabular}

figure 9 and 10 respectively. In this review when the first node dies to start, the network stability period decreases. Figure 9 and 10 shows that the FBECS protocol outperforms all the latest energy-efficient protocols, then SCHFTL, etc. 


\begin{tabular}{|c|c|c|c|c|c|}
\hline & & & & $\begin{array}{l}\text { - } \quad \text { farness to sink } \\
\text { Selection of message } \\
\text { forwarded node } \\
\text { - } \quad \text { Energy } \\
\text { - } \quad \text { farness to Sink } \\
\text { - } \quad \text { Cost }\end{array}$ & \\
\hline $\begin{array}{l}\text { SCCH (Izadi et } \\
\text { al., 2015)[34] }\end{array}$ & Homogenous & scattered & arbitrary & $\begin{array}{ll}- & \text { Node density } \\
- & \text { Node Centrality } \\
\text { - } & \text { Energy } \\
\end{array}$ & $\begin{array}{l}\text { Direct } \\
\text { communication }\end{array}$ \\
\hline $\begin{array}{l}\text { MCFL(Mirzaie } \\
\text { et al.,2017)[56] }\end{array}$ & Homogenous & Distributed & $\begin{array}{l}\text { Determine by } \\
\text { Sink }\end{array}$ & $\begin{array}{l}\text { - } \quad \text { Residual energy } \\
\text { - } \begin{array}{l}\text { No of neighbors of } \\
\text { each node. }\end{array}\end{array}$ & $\begin{array}{l}\text { Multi-hop } \\
\text { communication }\end{array}$ \\
\hline $\begin{array}{l}\text { EEDCF (Zhang } \\
\text { et al.,2017)[57] }\end{array}$ & Homogenous & scattered & Random & $\begin{array}{ll}\text { - } & \text { Residual energy } \\
\text { - } & \text { Node degree } \\
\text { - } & \text { Neighbor node } \\
\text { - } & \text { Average remaining } \\
& \text { energy. }\end{array}$ & $\begin{array}{l}\text { Direct } \\
\text { communication }\end{array}$ \\
\hline $\begin{array}{c}\text { FHRP(Neamatol } \\
\text { lahi et } \\
\text { al.,2017) }[58] \\
\end{array}$ & Homogenous & Distributed & Random & $\begin{array}{l}\text { - } \quad \text { Remaining energy } \\
\text { - } \quad \text { farness from the sink }\end{array}$ & $\begin{array}{l}\text { Multi-hop } \\
\text { communication }\end{array}$ \\
\hline $\begin{array}{l}\text { FUCA(Agrawal } \\
\text { et al.,2017)[51] }\end{array}$ & Homogenous & Distributed & $\begin{array}{l}\text { Determine by } \\
\text { Sink }\end{array}$ & $\begin{array}{ll}- & \text { Remaining energy } \\
\text { - } & \text { Node density } \\
\text { - } & \text { farness to Sink } \\
\text { - } & \text { Competition Radius } \\
\end{array}$ & $\begin{array}{l}\text { Direct } \\
\text { communication }\end{array}$ \\
\hline $\begin{array}{l}\text { FLECH } \\
\text { (Balakrishnan et } \\
\text { al.,2017)[47] }\end{array}$ & Homogenous & Distributed & $\begin{array}{l}\text { Determine by } \\
\text { Sink }\end{array}$ & $\begin{array}{ll}\text { - } & \text { Remaining energy } \\
\text { - } & \text { Node centrality } \\
\text { - } & \text { farness to Sink }\end{array}$ & $\begin{array}{l}\text { Direct } \\
\text { communication }\end{array}$ \\
\hline $\begin{array}{l}\text { FLEEC (Wang } \\
\text { et al.,2018)[59] }\end{array}$ & Homogenous & Distributed & $\begin{array}{l}\text { Determine by } \\
\text { Sink }\end{array}$ & $\begin{array}{ll}\text { - } & \text { Node density, } \\
\text { - } & \text { Distance-to-Sink, } \\
\text { - } & \text { Total-Distance } \\
\text { - } & \text { Residual-Energy } \\
\end{array}$ & $\begin{array}{l}\text { Direct } \\
\text { communication }\end{array}$ \\
\hline $\begin{array}{l}\text { TTDFP (Alper } \\
\text { et al.,2018)[60] }\end{array}$ & Homogenous & Distributed & Random & $\begin{array}{ll}\text { - } & \text { Distance to Sink } \\
\text { - } & \text { Remaining Energy } \\
\text { - } & \text { Relative Node } \\
& \text { Connectivity } \\
\text { - } & \text { Competition Radius } \\
\end{array}$ & $\begin{array}{l}\text { Direct } \\
\text { communication }\end{array}$ \\
\hline $\begin{array}{l}\text { FBECS (Mehra } \\
\text { et al., 2018)[46] }\end{array}$ & Homogenous & Distributed & $\begin{array}{l}\text { Determine by } \\
\text { Sink }\end{array}$ & $\begin{array}{ll}\text { - } & \text { Remnant energy } \\
\text { - } & \text { Node density } \\
\text { - } & \text { Distance to Sink } \\
\end{array}$ & $\begin{array}{l}\text { Direct } \\
\text { communication }\end{array}$ \\
\hline $\begin{array}{l}\text { SCHFTL (Ayati } \\
\text { et al.,2018)[48] }\end{array}$ & Homogenous & Distributed & $\begin{array}{l}\text { Determine by } \\
\text { Sink }\end{array}$ & $\begin{array}{ll}\text { - } & \text { Remnant Energy } \\
\text { - } & \text { Centrality } \\
\text { - } & \text { Communication } \\
& \text { quality } \\
\text { - } & \text { Dos attack } \\
\text { - } & \text { Total Delay } \\
\text { - } & \text { Distance from Sink }\end{array}$ & $\begin{array}{l}\text { Multi-hop } \\
\text { communication }\end{array}$ \\
\hline $\begin{array}{l}\text { E-CAFL (Mehra } \\
\text { et al.,2019)[49] }\end{array}$ & Homogenous & Distributed & $\begin{array}{l}\text { Determine by } \\
\text { Sink }\end{array}$ & $\begin{array}{ll}\text { - } & \text { Remaining Energy } \\
\text { - } & \text { Closeness to Sink } \\
\text { - } & \text { Density }\end{array}$ & $\begin{array}{l}\text { Direct } \\
\text { communication }\end{array}$ \\
\hline
\end{tabular}

The most important scenario that is used in many protocols is shown in Fig. 8. In this scenario, the Sink position is $(50,50)$ and the sensor node is deployed randomly, some protocols having more than one sink position. Table 3 showed a common simulation factor and their values which is very useful in radio communication.
If the sensor node starts communication then their life in terms of energy is reduced so for any network FND, QND, HND are important and after each round of communication check what is the node die state.

It is the actual fact that the energy accessible to sensing element nodes isn't solely restricted, however it's going to 
conjointly diminish terribly simply if it's not properly managed. The most reasons for the consumption of energy in wireless sensing element networks square measure communication and process, with communication being the most responsible for the consumption of energy. The energy model consists of 3 main modules: receiver, transmitter, and power electronic equipment.

The receiver consumes energy to run the receiver electronic equipment at the time of reception of information, and therefore the transmitter consumes energy to run the facility electronic equipment and transmitter electronic equipment at the time of transmission of information. Energy dissipation for transmitter and receiver is signify by $E$ elec and energy dissipation for transmit amplifier is signified by $E$ amp.

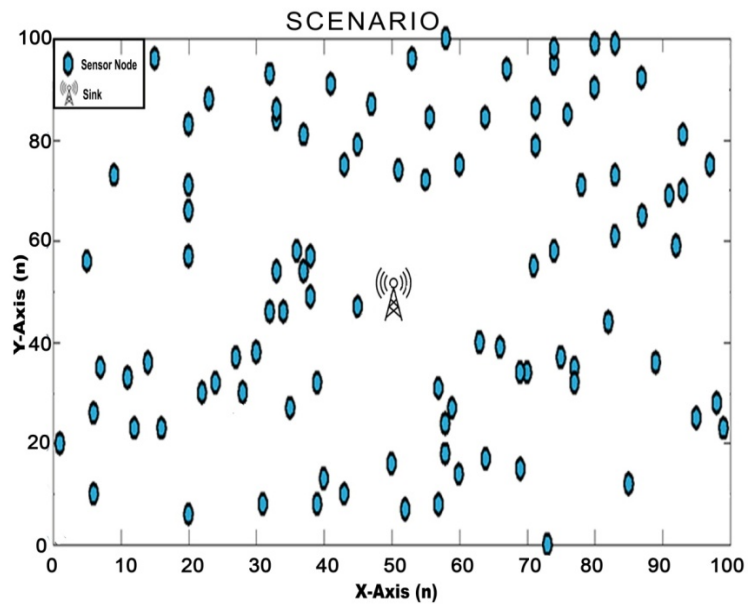

Figure 8. Common network scenario of WSN

Table 3. Common Simulation Parameters

\section{Conclusion}

Due to limited sources and accessibility, WSN calls for self-employing topology supervision and energy preservation strategies. Numerous strategies have been supplied to solve the energy preservation issue; however, a well-known and satisfying answer is the two-layer hierarchical structure and distributing various control functions, including energy efficiency, non-variance with multiple goals There are many sensor nodes that fail some time due to the worst routing protocols.

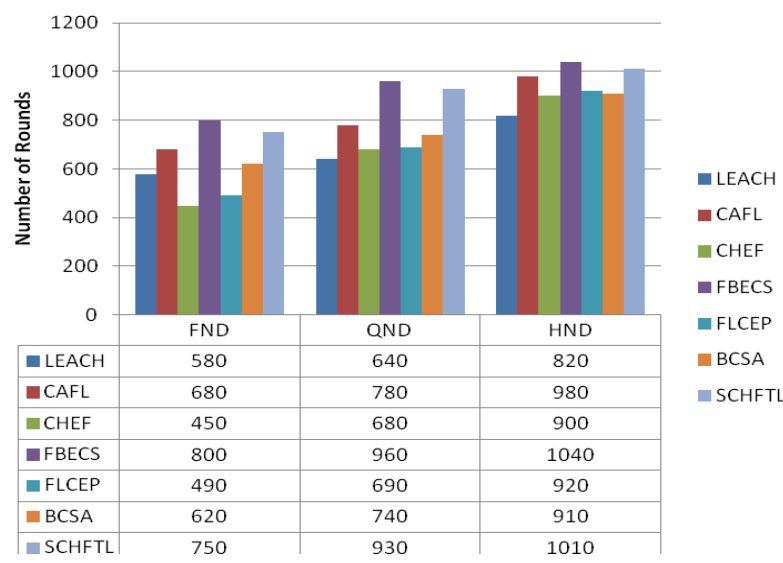

Figure 9. Comparison of various protocol in terms of First node die (FND), Quarter node die (QND), Half node die (HND) for $\mathrm{N}=100$

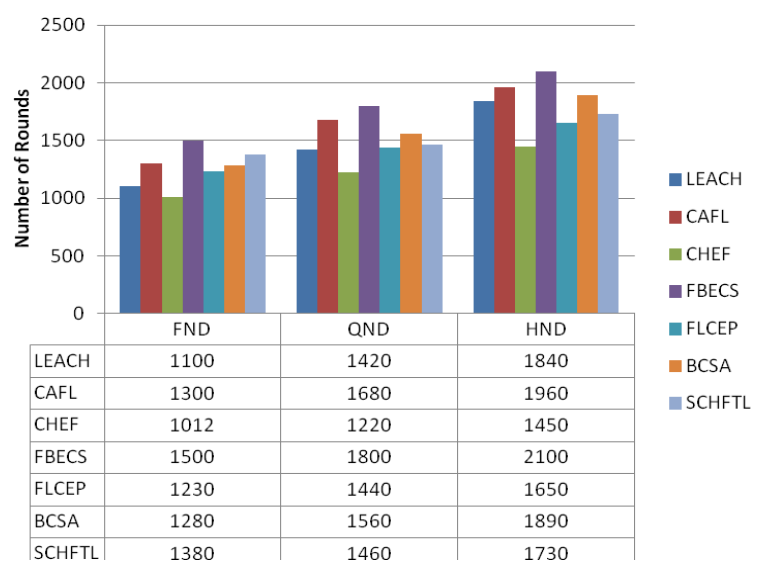

Figure 10. Comparison of various protocol in terms of FND, QND, HND for $\mathrm{N}=200$

\begin{tabular}{|l|l|}
\hline Factors & Values \\
\hline Sink Positions & $(50,50)$ \\
\hline Field & $(100 \mathrm{~m}$ X $100 \mathrm{~m})$ \\
\hline Preliminary Energy & $0.5 \mathrm{~J}$ \\
\hline $\begin{array}{l}\text { Free space magnification factor } \\
\mathscr{E} f \mathrm{~s}\end{array}$ & $10 \times 10-12 \mathrm{~J} / \mathrm{bit} / \mathrm{m} 2$ \\
\hline Magnification factor $\mathscr{E} \mathrm{mp}$ & $\begin{array}{l}0.0013 \times 10-12 \\
\mathrm{~J} / \mathrm{bit} / \mathrm{m} 4\end{array}$ \\
\hline n(total no of nodes) & 100,200 \\
\hline Select & $50 \mathrm{~nJ}$ \\
\hline EDA & $5 \mathrm{~nJ}$ \\
\hline Exploitation & arbitrary \\
\hline Header & 100 byte \\
\hline Packet length & 2000 byte \\
\hline
\end{tabular}

Fuzzy logic is applied to enhance the performance of a clustering strategy, but the most important challenge is that it calls for initial expert expertise to set a rule and select appropriate membership functions. Thus the various protocols produce different outputs with the same set of rules. The basic difference between the approaches is to become a $\mathrm{CH}$ using different participation factors to calculate the likelihood importance of the sensor node. Choosing a progressively effective, less intricate and 
dependable framework is a significant test since sensor systems are application-arranged where inclinations shift with organized targets to such an extent that data constancy is a higher need than higher fuzzy request frameworks, however, higher-request new difficulties utilizing the framework. But in this review paper, a lot of figures and tables have been told which have been studied from the last ten year papers and explained in detail to help researchers to create a novel approach which is helpful to create real-time applications. In the future, this review paper is very important for researchers and for various organizations, who work to design a real-time application based on the sensor node.

\section{References}

[1] "Wireless sensor networks: Architectures and protocols." .

[2] P. S. Mehra, M. N. Doja, and B. Alam, "Enhanced stable period for two level and multilevel heterogeneous model for distant base station in wireless sensor network," in Advances in Intelligent Systems and Computing, vol. 379, 2016, pp. 751-759.

[3] A. K. Singh, N. Purohit, and S. Varma, "Fuzzy logic based clustering in wireless sensor networks: a survey," Int. J. Electron., vol. 100, no. 1, pp. 126-141, Jan. 2013.

[4] M. Maksimović, V. Vujović, and V. Milošević, "Fuzzy logic and Wireless Sensor Networks-A survey," in Journal of Intelligent and Fuzzy Systems, 2014, vol. 27, no. 2, pp. 877-890.

[5] S. MAO and C. ZHAO, "Unequal clustering algorithm for WSN based on fuzzy logic and improved ACO," J. China Univ. Posts Telecommun., vol. 18, no. 6, pp. 89-97, Dec. 2011.

[6] S. Mao, C. Zhao, Z. Zhou, and Y. Ye, "An Improved Fuzzy Unequal Clustering Algorithm for Wireless Sensor Network," Mob. Networks Appl., vol. 18, no. 2, pp. 206-214, Apr. 2013.

[7] J. Kim, S. Park, Y. Han, and T. Chung, "CHEF: Cluster Head Election mechanism using Fuzzy logic in Wireless Sensor Networks," in Proceedings of 10th International Conference on Advanced Communication Technology, 2008, pp. 654--659.

[8] J.-S. Lee and W.-L. Cheng, "Fuzzy-Logic-Based Clustering Approach for Wireless Sensor Networks Using Energy Predication," IEEE Sens. J., vol. 12, no. 9, pp. 2891-2897, Sep. 2012.

[9] P. S. Mehra, M. N. Doja, and B. Alam, "Codeword Authenticated Key Exchange (CAKE) light weight secure routing protocol for WSN," Int. J. Commun. Syst., vol. 32, no. 3, p. e3879, Feb. 2019.

[10] H. Taheri, P. Neamatollahi, O. M. Younis, S. Naghibzadeh, and M. H. Yaghmaee, "An energy- aware distributed clustering protocol in wireless sensor networks using fuzzy logic," Ad Hoc Networks, vol. 10, no. 7, pp. 1469-1481, Sep. 2012.

[11] P. Gupta, P. Raj, S. Tiwari, P. Kumari, and P. S. Mehra, "Energy Efficient Diagonal Based Clustering Protocol in Wireless Sensor Network," SSRN Electron. J., Apr. 2020.

[12] Q. Wang, E. Kulla, G. Mino, L. Barolli, and J. Iwashige, "An integrated fuzzy logic system for cluster-head selection and sensor speed control in WSNs," in Proceedings - 2013 7th International Conference on Complex, Intelligent, and Software Intensive Systems, CISIS 2013, 2013, pp. 104110.

[13] Q. Wang, E. Kulla, G. Mino, and L. Barolli, "Prediction of sensor lifetime in wireless sensor networks using fuzzy logic," in Proceedings International Conference on Advanced Information Networking and Applications, AINA, 2014, pp. 1127-1131.

[14] I. Gupta, D. Riordan, and S. Sampalli, "ClusterHead Election Using Fuzzy Logic for Wireless Sensor Networks," in 3rd Annual Communication Networks and Services Research Conference (CNSR'05), 2005, pp. 255-260.

[15] A. Kumar, P. S. Mehra, G. Gupta, and A. Jamshed, "Modified Block Playfair Cipher using Random Shift Key Generation," Int. J. Comput. Appl., vol. 58, no. 5, pp. 975-8887, 2012.

[16] A. K. Dwivedi and A. K. Sharma, "NEEF: A Novel Energy Efficient Fuzzy Logic based Clustering Protocol for Wireless Sensor Network," Scalable Comput. Pract. Exp., vol. 21, no. 3, pp. 555-568, Aug. 2020.

[17] A. Kumar, P. S. Mehra, G. Gupta, and M. Sharma, Enhanced block Playfair Cipher, vol. 115. 2013.

[18] A. K. Dwivedi, A. K. Sharma, and R. Kumar, "Dynamic Trust Management Model for the Internet of Things and Smart Sensors: The Challenges and Applications," Recent Patents Comput. Sci., vol. 12, Aug. 2019.

[19] "Wireless Sensor Networks 2011-2021: IDTechEx.".

[20] G. D. Devi, "CLUSTERING ALGORITHMS IN WIRELESS SENSOR NETWORKS-A SURVEY.” 2013.

[21] R. Chanana, A. K. Singh, R. Killa, S. Agarwal, and P. S. Mehra, "Blockchain Based Secure Model for Sensor Data in Wireless Sensor Network," in 2020 6th International Conference on Signal Processing and Communication (ICSC), 2020, pp. 288-293.

[22] J.-M. Kim, S.-H. Park, Y.-J. Han, and T.-M. Chung, CHEF: Cluster Head Election mechanism using Fuzzy logic in Wireless Sensor Networks. IEEE, 2008, pp. 654-659.

[23] Y. M. Tashtoush and M. A. Okour, "Fuzzy selfclustering for wireless sensor networks," in Proceedings of The 5th International Conference 
on Embedded and Ubiquitous Computing, EUC 2008, 2008, vol. 1, pp. 223-229.

[24] "A Fuzzy Approach to Energy Optimized Routing for Wireless Sensor Networks." .

[25] A. S. Raghuvanshi, S. Tiwari, R. Tripathi, and N. Kishor, "Optimal number of clusters in wireless sensor networks: An FCM approach," in 2010 International Conference on Computer and Communication Technology, ICCCT-2010, 2010, pp. 817-823.

[26] G. Ran, H. Zhang, and S. Gong, "Improving on LEACH Protocol of Wireless Sensor Networks Using Fuzzy Logic," J. Inf. Comput. Sci., vol. 7, no. 3, pp. 767-775, 2010.

[27] D. Gong, Y. Yang, and Z. Pan, "Energy-efficient clustering in lossy wireless sensor networks," $J$. Parallel Distrib. Comput., vol. 73, no. 9, pp. 1323-1336, Sep. 2013.

[28] E. Saeedian, M. Jalali, M. M. Tajari, M. N. Torshiz, and G. Tadayon, "CFGA: Clustering wireless sensor network using fuzzy logic and genetic algorithm," in 7th International Conference on Wireless Communications, Networking and Mobile Computing, WiCOM 2011, 2011.

[29] F. Zhang, Q.-Y. Zhang, and Z.-M. Sun, "ICT2TSK: An improved clustering algorithm for WSN using a type-2 Takagi-Sugeno-Kang Fuzzy Logic System," in 2013 IEEE Symposium on Wireless Technology \& Applications (ISWTA), 2013, pp. 153-158.

[30] Jau-Ji Shen, Chih-Wei Lin, and Min-Shiang Hwang, "A modified remote user authentication scheme using smart cards," IEEE Trans. Consum. Electron., vol. 49, no. 2, pp. 414-416, May 2003.

[31] Z. W. Siew, A. Kiring, H. T. Yew, P. Neelakantan, and K. T. K. Teo, "Energy efficient clustering algorithm in wireless sensor networks using fuzzy logic control," in 2011 IEEE Colloquium on Humanities, Science and Engineering, CHUSER 2011, 2011, pp. 392-397.

[32] S. Ben Alla, A. Ezzati, and A. Mohsen, "Gateway and cluster head election using fuzzy logic in heterogeneous wireless sensor networks," in Proceedings of 2012 International Conference on Multimedia Computing and Systems, ICMCS 2012, 2012, pp. 761-766.

[33] R. Mhemed, N. Aslam, W. Phillips, and F. Comeau, "An Energy Efficient Fuzzy Logic Cluster Formation Protocol in Wireless Sensor Networks," Procedia Comput. Sci., vol. 10, pp. 255-262, Jan. 2012.

[34] D. Izadi, J. Abawajy, and S. Ghanavati, "A new energy efficient cluster-head and backup selection scheme in WSN," in Proceedings of the 2013 IEEE 14th International Conference on Information Reuse and Integration, IEEE IRI 2013, 2013, pp. 408-415.

[35] W. A. Afifi and H. A. Hefny, "Adaptive TAKAGI-SUGENO fuzzy model using weighted fuzzy expected value in wireless sensor network," in 2014 14th International Conference on Hybrid Intelligent Systems, HIS 2014, 2003, pp. 225-231.

[36] H. Natarajan and S. Selvaraj, "A Fuzzy Based Predictive Cluster Head Selection Scheme for Wireless Sensor Networks."

[37] X.-S. Yi, P.-J. Jiang, X.-W. Wang, and S.-C. Zhang, "Survey of Energy-Saving Protocols in Wireless Sensor Networks," in 2011 First International Conference on Robot, Vision and Signal Processing, 2011, pp. 208-211.

[38] Q. Y. Zhang, Z. M. Sun, and F. Zhang, "A clustering routing protocol for wireless sensor networks based on type-2 fuzzy logic and ACO," in IEEE International Conference on Fuzzy Systems, 2014, pp. 1060-1067.

[39] S. Rana, A. N. Bahar, N. Islam, and J. Islam, "Fuzzy Based Energy Efficient Multiple Cluster Head Selection Routing Protocol for Wireless Sensor Networks," Int. J. Comput. Netw. Inf. Secur., vol. 7, no. 4, pp. 54-61, Mar. 2015.

[40] H. El Alami and A. Najid, "Energy-efficient fuzzy logic cluster head selection in wireless sensor networks," in 2016 International Conference on Information Technology for Organizations Development (IT4OD), 2016, pp. 1-7.

[41] M. Toloueiashtian and H. Motameni, "A new clustering approach in wireless sensor networks using fuzzy system," J. Supercomput., vol. 74, no. 2, pp. 717-737, Feb. 2018.

[42] P. S. Mehra, M. N. Doja, and B. Alam, "Stable Period Enhancement for Zonal (SPEZ)-Based Clustering in Heterogeneous WSN," in Smart Innovation, Systems and Technologies, vol. 79, Springer, Singapore, 2018, pp. 887-896.

[43] A. Mahboub, E. M. En-Naimi, M. Arioua, H. Barkouk, Y. El Assari, and A. El Oualkadi, "An energy-efficient clustering protocol using fuzzy logic and network segmentation for heterogeneous WSN," Int. J. Electr. Comput. Eng., vol. 9, no. 5, pp. 4192-4203, Oct. 2019.

[44] A. Pires, C. Silva, E. Cerqueira, D. Monteiro, and R. Viegas, "CHEATS: A cluster-head election algorithm for WSN using a Takagi-Sugeno fuzzy system," in 2011 IEEE Latin-American Conference on Communications, LATINCOM 2011 - Conference Proceedings, 2011.

[45] H. Bagci and A. Yazici, "An energy aware fuzzy approach to unequal clustering in wireless sensor networks," Appl. Soft Comput., vol. 13, no. 4, pp. 1741-1749, Apr. 2013.

[46] P. S. Mehra, M. N. Doja, and B. Alam, "Fuzzy based enhanced cluster head selection (FBECS) for WSN," J. King Saud Univ. - Sci., vol. 32, no. 1, pp. 390-401, Apr. 2020.

[47] B. Balakrishnan and S. Balachandran, "FLECH: Fuzzy logic based energy efficient clustering hierarchy for nonuniform wireless sensor networks," Wirel. Commun. Mob. Comput., vol. 2017, 2017.

[48] M. Ayati, M. H. Ghayyoumi, and A. KeshavarzMohammadiyan, "A fuzzy three-level clustering 
method for lifetime improvement of wireless sensor networks," Ann. des Telecommun. Telecommun., vol. 73, no. 7-8, pp. 535-546, 2018.

[49] P. S. Mehra, M. N. Doja, and B. Alam, "Enhanced Clustering Algorithm based on Fuzzy Logic (E-CAFL) for WSN," Scalable Comput. Pract. Exp., vol. 20, no. 1, pp. 41-54, Mar. 2019.

[50] S. A. Sert, H. Bagci, and A. Yazici, "MOFCA: Multi-objective fuzzy clustering algorithm for wireless sensor networks," Appl. Soft Comput., vol. 30, pp. 151-165, May 2015.

[51] D. Agrawal and S. Pandey, "FUCA: Fuzzy-based unequal clustering algorithm to prolong the lifetime of wireless sensor networks," Int. J. Commun. Syst., vol. 31, no. 2, pp. 34-48, Jan. 2018.

[52] A. Kumar Dwivedi, A. Kumar Sharma, and P. Singh Mehra, "Energy Efficient Sensor Node Deployment Scheme for Two Stage Routing Protocol of Wireless Sensor Networks assisted IoT," ECTI Trans. Electr. Eng. Electron. Commun., vol. 18, no. 2, pp. 158-169, Aug. 2020.

[53] O. Younis and S. Fahmy, "HEED: a hybrid, energy-efficient, distributed clustering approach for ad hoc sensor networks," Mob. Comput. IEEE Trans., vol. 3, no. 4, pp. 366-379, 2004.

[54] R. Jin, N. Wei, X. Shi, T. Gao, and J. Zou, "Clustering routing protocol based on fuzzy inference for WSNs," in 7th International Conference on Wireless Communications, Networking and Mobile Computing, WiCOM 2011, 2011.

[55] C. Mohan, Suman, and A. Kumar, "Heterogeneous fuzzy based clustering protocol," in 2013 IEEE 2nd International Conference on Image Information Processing, IEEE ICIIP 2013, 2013, pp. 601-606.

[56] M. Mirzaie and S. M. Mazinani, "MCFL: an energy efficient multi-clustering algorithm using fuzzy logic in wireless sensor network," Wirel. Networks, pp. 1-16, Feb. 2017.

[57] Y. Zhang et al., "Fuzzy-Logic Based Distributed Energy-Efficient Clustering Algorithm for Wireless Sensor Networks," Sensors, vol. 17, no. 7, p. 1554, Jul. 2017.

[58] P. Neamatollahi, M. Naghibzadeh, and S. Abrishami, "Fuzzy-Based Clustering-Task Scheduling for Lifetime Enhancement in Wireless Sensor Networks," IEEE Sens. J., vol. 17, no. 20, pp. 6837-6844, Oct. 2017.

[59] Q. Wang, D. Lin, P. Yang, and Z. Zhang, "A Fuzzy-logic Based Energy-efficient Clustering Algorithm for the Wireless Sensor Networks," in 2018 26th International Conference on Software, Telecommunications and Computer Networks (SoftCOM), 2018, pp. 1-6.

[60] S. A. Sert, A. Alchihabi, and A. Yazici, "A TwoTier Distributed Fuzzy Logic Based Protocol for Efficient Data Aggregation in Multihop Wireless Sensor Networks," IEEE Trans. Fuzzy Syst., vol.
26, no. 6, pp. 3615-3629, Dec. 2018. 